International Journal of English Literature and Social Sciences
Vol-6, Issue-5; Sep-Oct, 2021

Peer-Reviewed Journal

\title{
Portrayal of the Hindu - Parsi Zoroastrian Community Conflicts in India through Rohinton Mistry's Novels
}

\author{
Mr. A. Yogaraj ${ }^{1}$, Dr. Mrs. M. Kavitha² \\ ${ }^{1}$ Part-Time - Ph.D., Research Scholar in English, Department of English, Park's College, Tiruppur, Tamilnadu, India \\ ${ }^{2}$ Associate Professor, Head and Research Supervisor, Department of English, Park's College, Tiruppur, Tamilnadu, India
}

Received: 24 Sep 2021; Received in revised form: 14 Oct 2021; Accepted: 22 Oct 2021; Available online: 28 Oct 2021

(C)2021 The Author(s). Published by Infogain Publication. This is an open access article under the CC BY license

(https://creativecommons.org/licenses/by/4.0/).

\begin{abstract}
Literature has always represented society in one form or another because writers are the sensitive souls of the society who are affected by the slightest possible change in their surroundings. These changes get reflected through their works and many times these sound discordant and distressing notes on the behalf of a certain section of the society. This paper deals with Indian literature especially focuses on Indian Diasporic writer Rohinton Mistry who represents the realistic picture of the Parsi religious community as a minority in India. Most of his concerns are devoted towards the preservation of the Parsi Community which is fast moving towards its extinction. And the present paper provides authentic and scholarly insights into Zoroastrian's faith, beliefs, values, customs, rituals and a brief history of Zoroastrianism in light of Rohinton Mistry's fiction. His concerns for the socially downtrodden and socially marginalized have found genuine representation in his works like-Such a Long Journey, A Fine Balance and Family Matters. How these races and communities survive during the periods of intense anarchy will be the topic of discussion of this paper.
\end{abstract}

Keywords_Indian Society, Parsi Community, Socially downtrodden, Preservation, Anarchy.

\section{INTRODUCTION}

Rohinton Mistry was born in Bombay, India, to a Parsi family. His brother is the playwright and author Cyrus Mistry. He earned a BA in Mathematics and Economics from St. Xavier's College, Bombay. He emigrated to Canada with his wife to be Freny Elavia in 1975 and they married shortly afterwards. He worked in a bank for a while, before returning to academia at the University of Toronto where he obtained a BA in English and Philosophy. While attending the University of Toronto, he became the first to win two Hart House literary prizes for stories published in the Hart House Review and Canadian Fiction Magazine's annual Contributor's Prize for 1985.

Three years later, Penguin Book Canada published his collection of 11 short stories, Tales from Firozsha Baag. It was later published in the United States as Swimming Lessons and Other Stories from Firozsha Baag. His second book, the novel Such a Long Journey, was published in 1991. It won the Governor General's Award, the Commonwealth Writers
Prize for Best Book, and the W.H. Smith/Books in Canada First Novel Award. It was shortlisted for the Booker Prize and for the Trillium Award. It has been translated into German, Swedish, Norwegian, Danish, and Japanese. It was adapted for the 1998 film Such a Long Journey. The content of the book caused a controversy at Mumbai University in 2010 due to language used against Bal Thackeray, leader of Shiv Sena, a political party from Maharashtra, as well as some remarks about Maharashtrians. His third book, and second novel, A Fine Balance (1995), won the second annual Giller Prize in 1995, and the Los Angeles Times Book Prize for Fiction in 1996. It was selected for Oprah's Book Club in November 2001. It won the 1996 Commonwealth Writers Prize and was shortlisted for the 1996 Booker prize. His third novel, Family Matters (2002) is a consideration of the difficulties that come with ageing, to which topic Mistry returned in 2008 with the short fiction The Scream (published as a separate volume, in support of World Literacy of Canada). 


\section{Theme of the Novels}

Rohinton Mistry's novels often deal with the life of Indians who suffer from communal disharmony, religious and caste discriminations, religious Chauvinism, ethnicity and cultural diversities. His novels mainly present realistic picture of the minority community of the Parsi people, its fears, anxieties, sense of insecurity, helplessness because of the political uncertainties. He raises some problems of minorities and cultural crisis which are the main issues under the subaltern studies, a key term of post-colonial theory. And his novel Family Matters in which he has shown these minority issues after the time of demolition of Babri Mosque. Besides these it will present the threat of declining population of Parsis.

\section{THE HISTORICAL PERSPECTIVES OF PARSIS}

The Parsis are followers of Prophet Zarathustra of Iran, whose Greek name is Zoroaster, who is believed to have preached a message of the one true god (monotheism), Ahura Mazda during the Bronze age between 625-551 BC. Legend tells us that his origin was divine. It is believed that Zarathustra left behind him nearly two million verses in the form of hymns and meditations but these writings were lost and some were destroyed by fire. However, in the later years these were written down by the fugitive Magian priests from memory and the message that he preached was detailed in the Gathas (or Songs of Wisdom), known as the core of the Zend Avesta, the sacred Zoroastrian text (Ahuja, 2008). Zoroastrianism was the predominant religion of Iran until the fall of the Sasanian Empire in the mid-7 th century, after which Iran steadily adopted Islam. In contrast, the Zoroastrians in India, who became known as the Parsis, became a prosperous and well-respected community of merchants in western India, increasingly focused in Bombay.

\section{THE PRINCIPLE TEACHINGS OF ZARATHUSTRA}

Zoroastrianism stress on ethics, its positive approach to life, optimism about the future of the world. It's emphasis on free choice and its catholicity. Zarathustra pointed out that in each of us there is a divine spark. It is up to us to recognize this divine spark as a practical guide in daily life, his prescription was very simple:

- Think good thoughts

- Speak good words

- Do good deeds

It is important to know the values stressed in Zoroastrianism.
Truth: Zoroastrianism stresses truth more than anything else. A free translation of that prayer called AshemVohy is: truth is the greatest virtue.

Charity: In the very second prayer a Zoroastrianism child learns - the 'Yatha Ahuvairyo'. There is a saying: "Parsi, thy name is charity"

Purity: Purity of the body as well as that of the mind. This is why a Zoroastrian is expected to take a bath before any important ceremony.

Dignity of labour: Zoroastrianism also stresses hard work and dignity of labour

Freedom: Freedom is a fundamental value in Zoroastrian ethics, the humanity of moral agent requires that man or women should be free to choose and then be held responsible for that choice

\section{INTER - MARRIAGE DISPUTE OF THE PARSI COMMUNITY}

Another important factor is the potential role of inter-marriage rules prevailing among the Parsi community. This ethno-religious group is an endogamous and nonproselytizing community, which has traditionally refused to convert people of other faiths, and that requires a Parsi father as a necessary legal condition for a newborn to be considered a Parsi. Therefore, if a Parsi woman marries a non-Parsi man her offspring will not be considered a Parsi. She will remain a member of the Parsi community by law, but not by custom, according to orthodox Parsis. If a Parsi man marries a nonParsi woman, his offspring will be considered Parsi; his wife, however, will not be a Parsi.

\section{CONFLICTS OF THE HINDU RELIGIOUS CASTE SYSTEM}

India is a country where almost all the religions of the world found representation and has given birth to four important religions of the world, namely Hinduism, Buddhism, Jainism, and Sikhism. And Caste system has been a glaring, tragic fact of life ever since Manu Smriti divided the society into four castes-Brahmin, Kshatriya, Vaishya and Shudra. Although condemned for oppressing and exploiting the lower caste, especially Shudras, the system has been justified as sanctioned by the scriptures by interested parties in spite of several social reform movements initiated in the twentieth century by Mahatma Gandhi and B. R. Ambedkar, who worked for social equality all through their lives. Abolition of untouchability and ending discrimination on the basis of caste is a fundamental principle of the Indian Constitution, yet we find that it is still being practiced in various parts of the country, especially in rural areas. 


\section{RELIGIOUS VIEW OF SUCH A LONG JOURNEY}

That may be, but ours prophet Zarathustra lived more than fifteen hundred years before your son of god was even born; A thousand years before the Buddha; two hundred years before Moses. And do you know how much Zoroastrianism influenced Judaism, Christianity and Islam?". Critics have pointed out the possible influence of zorastriansim on judaism and chistianity in the following theological concepts which are shred by all the three religions.

1. Belief in one supreme and loving god.

2. The concept of heaven and hell and individual judgement.

3. A strict moral and ethical code and a belief in the ultimate triumph of good.

4. The messiah to come for the final restoration.

5. The concept of resurrection final judgement and life ever lasting.

6. The zoroastrian origin of words like Satan paradise pastor and amen.

Rohinton Mistry's first novel, 'Such a Long Journey', deals with parsis and parsi life, certain customs, rituals related to the microscopic community are graphically described. The inhabitants of the Khodadad building are representatives of a cross-section of middle-class Parsis expressing all the angularities of the dwindling community. Gustad is introduced through his morning prayer. The way he put on 'Kusti' and uttered his prayers would give a non-parsi a clear idea of parsi ritual: "Gustad finished retying the 'Kusti' round his waist and noted with satisfaction that the two ends as usual, were of equal length. He raised and lowered his shoulders to let his "Sudra" settle comfortably around him. He turned his face to the sky eyes closed and began reciting the SaroshBaaj, silently forming the worlds with his lips".

Gustad Noble, the protagonist of the novel, Such a Long Journey, reflects this thinking of his community right from the beginning to the end. He shows enough patience to hear the stories of his Catholic friend, Malcolm Saldanah, but is careful not to be impressed with them and stick to the ideology of his own religion. Throughout the novel, there are many instances of Parsi characters showing social and political insecurity in the state and country. Dinshawji expresses his concern over the growing strength of Shiv Sena in Maharashtra and recalls the day when their bank was vandalized by the Shiv Sena hooligans. Mistry openly criticizes Shiv Sena and its intolerance towards members of other communities and considers it the root cause of the Parsis not being able to feel secure in a city that once throbbed with Parsis. In an effort to preserve the compound wall of Khodadad Building, Gustad requests the pavement artist to draw pictures of Gods and Goddesses on it but realizing that the Hindus may not show reverence to Ahura Mazda or his Prophet Zarathustra, he asks the artist to draw pictures of Gods from all religions of the world. This has a drastic effect and people stop misusing the wall. Gustad's visit to the Towers of Silence during Dinshawji's and Major Bilimoria's funerals highlights the sanctity and peace one feels in such places. Gustad feels himself lost in the music emanating from the ancient prayers offered by a dustoor for the departed soul.

But in all seriousness, through his fiction, Mistry has promoted allegiance to the faith. The Zoroastrians believe that the world has two prevailing forces, i.e. the good and the bad and in the fight between good and the bad, ultimately good forces will emerge winner. Such a Long Journey is an example of this religious philosophy in which, the protagonist, Gustad Noble is shown to fight these forces all through his life but at the end his reunion with his son, Sohrab, is the victory of his faith.

\section{HINDU CASTE SETBACK IN A FINE BALANCE}

The author Rohinton Mistry again shows the protagonists trying to strike a balance between the good and bad forces. Dina is fighting to maintain her individuality and her independence. In this novel, particularly, Mistry exhibits another kind of 'other' that he never touched upon in his earlier works. These 'other' are Ishvar and Om, the representatives of the Hindu low-caste community or the untouchables who have been subdued by the upper castes in India from times immemorial. As per traditional Hindu customs described in Manusmriti, the law book of Manu, who according to Hindu mythology was the mind-born son of the Creator, Lord Brahma, socially the Hindus are divided into four castes- the upper caste Brahmins, the Kshatriyas, the Vaishyas and the lowest caste, Sudras. The castes depicted the profession of the individuals in the society but with the passage of time caste system became rigid and the person was confined to his caste from the time of his birth. It became essential for people to follow the trade of their caste. The caste system which had earlier united the society in an organic whole slowly became an instrument at the hands of the upper caste to wield power over the lower castes.

Dukhi's Adversity

Dukhi belongs to the lowest Chamaar caste in the village. The Chamaars' livelihood depends on the death of a cow or buffalo in the village, their job being to remove the carcass, which is sometimes given free or has to be paid for, depending on whether or not the upper-caste owner had been able to extract enough free labour from the Chamaars during the year. The Chamaars skin the carcass, eat the meat, and tan 
the hide which is turned into sandals, whips, harnesses and water skins. Every leather-worker stink. Dukhi learns the ancestral profession at the age of five and the odour of dead animals lingers on his body. The Chamaars live in a small, secluded downstream corner of this village by a river- away from the Brahmins and landowners, who treat them worse than filth or scum of the earth. Anyone accused of or caught stealing, like Bhola, has his left-hand fingers chopped off, but he is considered lucky because he doesn't like Chhagan, lose his hand at the wrist. They keep their ears to the ground for a dying or dead animal in the village and help one another in removing the carcass and skinning it. They live from hand to mouth and are made to slave for free for the upper castes; their women are molested and raped; they are mercilessly beaten for the most trivial offences, and made to toe the line dividing them from the upper castes. Their living conditions force them to steal as does Dukhi's wife Roopa. She gets up very early in the morning and goes around stealing milk from cows in order to feed her sons Narayan and Ishvar.

In those heady days of independence, there is lot of talk regarding eradication of social inequalities but nothing is done in practice. In the village his sons are not even allowed to enter the school. When they try to sneak in during recess, they are publicly beaten by the teacher and humiliated. The village pundit Lailluram tries to justify the teacher's action; he only gives Dukhi an ointment to apply on his sons' backs to lessen the pain of caning. Dukhi has to hear a long and tedious lecture on the caste system and how one must perform one's duty as lay down in the scriptures. He throws away the ointment the Pandit gave him as it looks like boot polish. It is then that Dukhi makes up his mind to send his sons to Ashraf in town to be apprenticed to him as tailors. Ashraf receives Narayan and Ishvar, warmly and affectionately.

\section{PARSI COMMUNITY IN FAMILY MATTERS}

Rohinton Mistry's novel Family Matters, which focuses on religious extremism within the minority Parsi community. The novel suggests that the individual needs to maintain 'a fine balance' between religious beliefs and personal rights. It recognises that secularisation has shaped modern religious identity and, consequently, facilitated religious extremism. By de-coupling religion from secularisation, Mistry demonstrates that religion need not be rigid and can adapt to different social circumstances, while continuing to provide moral strength.

\section{CONCLUSION}

Thus, Rohinton Mistry's fiction is full of the depiction of the Parsi community, Indian politics, minority and many aspects of India, such as war, identity, cast system, etc. After immigration to Canada, he comes back or returns to Indian for the theme and his all works are full of Indianness which has been shown the real picture of post-independence India. Most of the themes such as rituals, religious communitarian identities, human relations, the middle class, and friendship are seeing in his fiction. In his fiction, he portrays the Parsi Community and the present conditions of suffering fear and their loss of the social, economic and political significance of the Parsi community. He declared the status of the Parsi community in India.

\section{REFERENCES}

[1] Mistry, Rohinton Such A Long Journey. London: Faber \& Faber, 1991

[2] Mistry, Rohinton. A Fine Balance. Toronto, McClelland \& Steward, 1995

[3] Mistry Rohinton. Family Matters. London : Faber \& Faber, 2006.

[4] Bharucha E Nilufer, Repossessing the Master Tongue, Subverting the Master Narrative and Challenging the Metanarrative of History: Rohinton Mistry's Fiction. Ed. Anjali Gera Roy, Meena T Pillai, Pen Craft International 2007, P 40.

[5] Brass, Paul R. The Politics of India since Independence. Cambridge, Cambridge University Press, 1990.

[6] Charu Chandra Mishra, Modes of Resistance in Rohinton Mistry's Such a Long Journey, Ed Novy Kapadia, JaydipSinh Dodiya, R.K Dhawan Prestige Books 2001, P 164.

[7] Vibhuti wadhawan. Parsi Community and the Challenges of Modernity: A Reading of Rohinton, Mistry's Fiction New Delhi: Prestige books International, 2014

[8] Jagdish Barta. Roshinton Mistry Identity values and other sociological concerns. New Delhi: Prestige books, 2008.

[9] Santwana Hadlar. Rohinton Mistry's such long journey: A Critical Study. New Delhi: Asia book club, 2006.

[10] N.P. Sharma. Parsi Culture and vision in Rohinton Mistry Such A Long Journey and firdaus kanga's trying to grow: A comparative study New Delhi: Prestiage books.1998.

[11] Jaydipsinh Dodiya. The Fiction of Rohinton Mistry: Critical Studies, New Delhi Prestige Books 1998.

[12] Jaydipsinh Dodiya. Perspectives on the Novels of Rohinton Mistry. New Delhi: Sarup \& Sons, 2006.

[13] Ahuja, M L. Major Religions of the World. New Delhi: UBSPD, 2008. Print.

[14] Bhautoo-Dewnarain, Nandini.Rohinton Mistry: An Introduction. New Delhi: Foundation Books, 2007. Print.

[15] FEZANA. Demographic Research. Volume-25, Article 17 http://www.demographic-research.org 547. 2012 Web.

[16] Framjee, Dosabhoy. The Parsees: Their History, Manners, Customs, and Religion. London: Smith, Elder and Co., 1858 Print.

[17] Registrar General of India (Census 2001), National Informatics Centre. New Delhi.

[18] Shroff, Zubin C. \& Marcia C. Castro. "The Potential Impact of Intermarriage on the Population Decline of the Parsis of 
Mumbai, India” http://creativecommons.org 26 Aug 2012. Web.

[19] Visaria 1974, Unisa et al. "Demographic Predicament of Parsis in India" Indian Institute for Population Sciences, Mumbai, India.www.iipsindia.org 7 Sep 2011. Web.

[20] Waugh, Patricia. Literary Theory and Criticism. New Delhi: OUP, 2006. Print.

[21] Maneck, Susan Stiles.The Death of Ahriman: Culture, Identity and _. Abstract. Ph.D. Dissertation. UA Campus Repository University Libraries. http://www.library.arizona.edu 12 Jan 2011. Web.

[22] Patel, Dinyar. "Understanding Parsi Population Decline in India: A Historical Perspective" Ph. D. Thesis. Jawaharlal Nehru Centre, Mumbai. 7 May 2011. Web.

[23] Roy, Anjali Gera \&Meena T Pillai, ed. Rohinton Mistry: An Anthology of Recent Criticism. New Delhi: Pencraft, 2007. Print. 